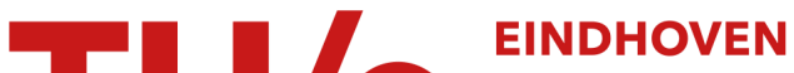 UNIVERSITY OF TECHNOLOGY
}

\section{IEEE Wireless Power Week 2019 [Conference Report]}

Citation for published version (APA):

Visser, H. J., Mitcheson, P. D., Lan, L., \& Arteago Saenz, J. (2019). IEEE Wireless Power Week 2019 [Conference Report]. IEEE Microwave Magazine, 20(11), 111-113. [8866791].

https://doi.org/10.1109/MMM.2019.2935391

\section{Document license:}

TAVERNE

DOI:

10.1109/MMM.2019.2935391

Document status and date:

Published: 01/11/2019

\section{Document Version:}

Publisher's PDF, also known as Version of Record (includes final page, issue and volume numbers)

\section{Please check the document version of this publication:}

- A submitted manuscript is the version of the article upon submission and before peer-review. There can be important differences between the submitted version and the official published version of record. People interested in the research are advised to contact the author for the final version of the publication, or visit the $\mathrm{DOI}$ to the publisher's website.

- The final author version and the galley proof are versions of the publication after peer review.

- The final published version features the final layout of the paper including the volume, issue and page numbers.

Link to publication

\section{General rights}

Copyright and moral rights for the publications made accessible in the public portal are retained by the authors and/or other copyright owners and it is a condition of accessing publications that users recognise and abide by the legal requirements associated with these rights.

- Users may download and print one copy of any publication from the public portal for the purpose of private study or research.

- You may not further distribute the material or use it for any profit-making activity or commercial gain

- You may freely distribute the URL identifying the publication in the public portal.

If the publication is distributed under the terms of Article 25fa of the Dutch Copyright Act, indicated by the "Taverne" license above, please follow below link for the End User Agreement:

www.tue.nl/taverne

Take down policy

If you believe that this document breaches copyright please contact us at:

openaccess@tue.nl

providing details and we will investigate your claim. 


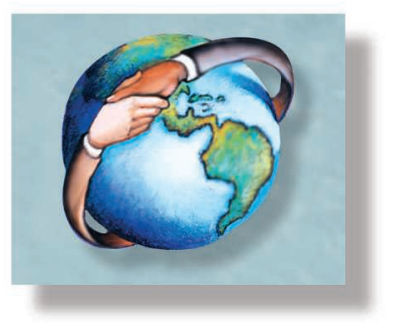

\section{Conference Report}

\section{IEEE Wireless Power Week 2019}

- Hubregt J. Visser, Paul D. Mitcheson, Lingxin Lan, and Juan Arteaga Saenz

$\mathrm{I}$ EEE Wireless Power Week 2019 (WPW2019) was held 18-21 June 2019 in London, United Kingdom, a location of great historical relevance to the field. WPW2019 consisted of the IEEE Microwave Theory and Techniques Society Wireless Power Transfer Conference (WPTC) 2019 and the IEEE Power Electronics Society Workshop on Emerging Technologies: Wireless Power (WoW) 2019.

This year's conference was the second edition of WPW, which started last year in Montréal. The event was held in Savoy Place, the headquarters of the Institution of Engineering and

Hubregt J.Visser (h.j.visser@tue.nl) is with the Eindhoven University of Technology, The Netherlands. Paul D. Mitcheson (paul .mitcheson@imperial.ac.uk),Lingxin Lan (lingxin.lan14@imperial.ac.uk), and Juan Arteaga Saenz (j.arteaga-saenz15@imperial .ac.uk) are with Imperial College London.

Digital Object Identifier 10.1109/MMM.2019.2935391 Date of current version: 11 October 2019

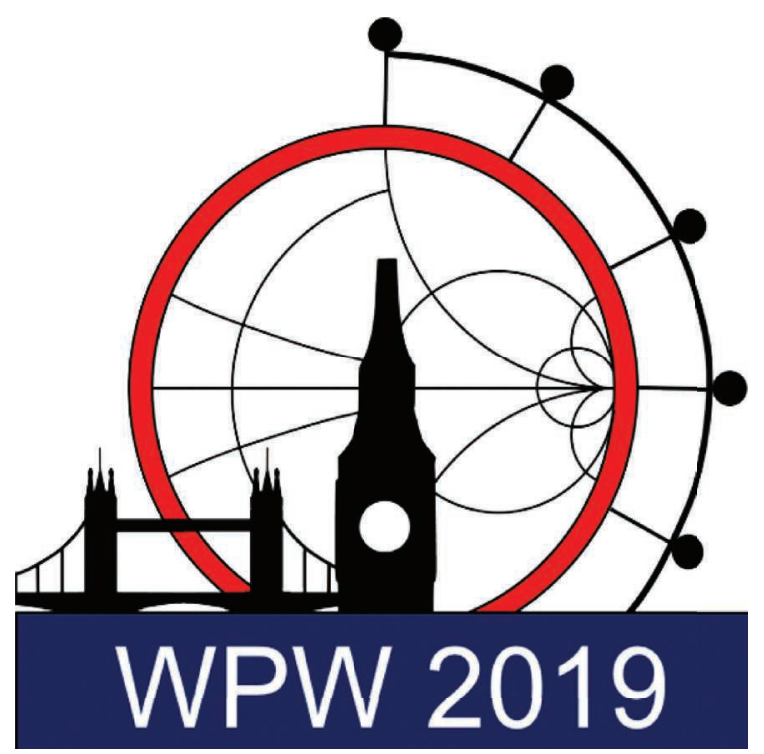

to the British Broadcasting Corporation from 1923 to 1932.

The conference was preceded on 17 June by the WPW2019 school (Figure 1), a one-day event held at Imperial College London and chaired by Nuno Borges Carvalho (University of Aveiro, Portugal). During the wellattended school (50 preregistrations and five on-site registrations), 10 experts in the field of near- and farfield wireless power transfer presented lectures to update Ph.D. degree candidates and newcomers to the field.

All papers submitted to Technology (IET), which was formed in 2006 from the union of the Institution of Electrical Engineers (IEE), founded in 1871, and the Institution of Incorporated Engineers, founded in 1884. Savoy Place's history dates to 1246 . The current building was completed in 1889 and served as an examination hall for the Royal College of Physicians and the Royal College of Surgeons. In 1909, the IEE bought the lease. It offered accommodation
WPW2019 were thoroughly reviewed by the joint WPTC-WoW technical program committees. A total of 302 papers were submitted by 1,012 authors from 41 countries. Of those, 146 were accepted for WPTC (an acceptance rate of 74.9\%), and 85 were accepted for WoW (82.5\%). Roughly half (49\%) of the authors had an academic affiliation while $34 \%$ were students, $21 \%$ were connected to industry, $3 \%$ were in government, and $1 \%$ worked for nongovernmental organizations. 
The WPW2019 opening reception took place on the roof terrace of Savoy Place, providing a magnificent view of old and new London (Figure 2).
At the official opening of the conference, many people were rightfully impressed by the grandeur of the Kelvin Lecture Theatre (Figure 3).

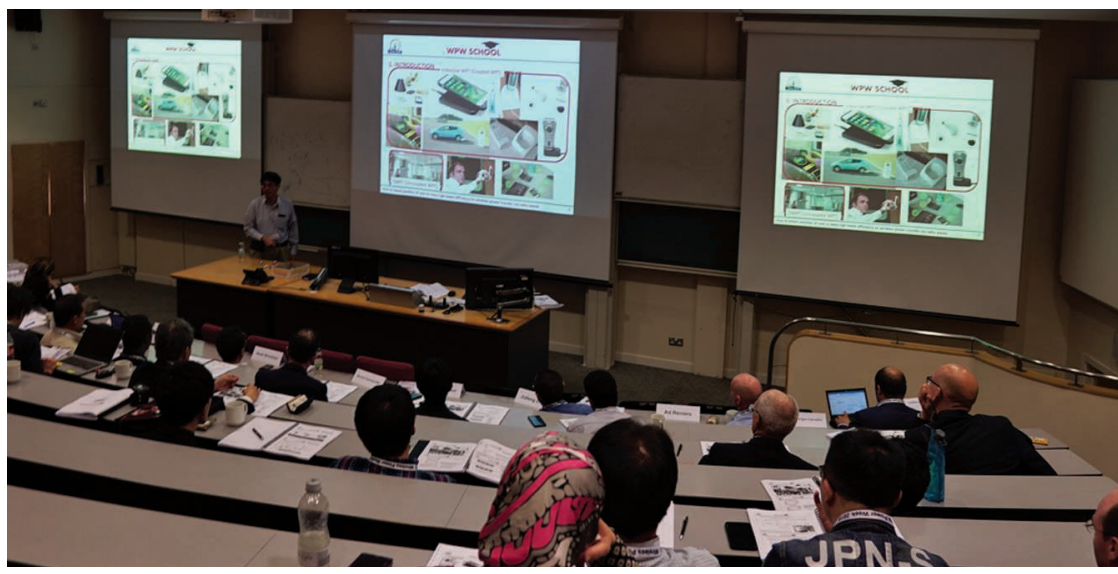

Figure 1. The WPW2019 school at Imperial College London attracted more than 50 people.

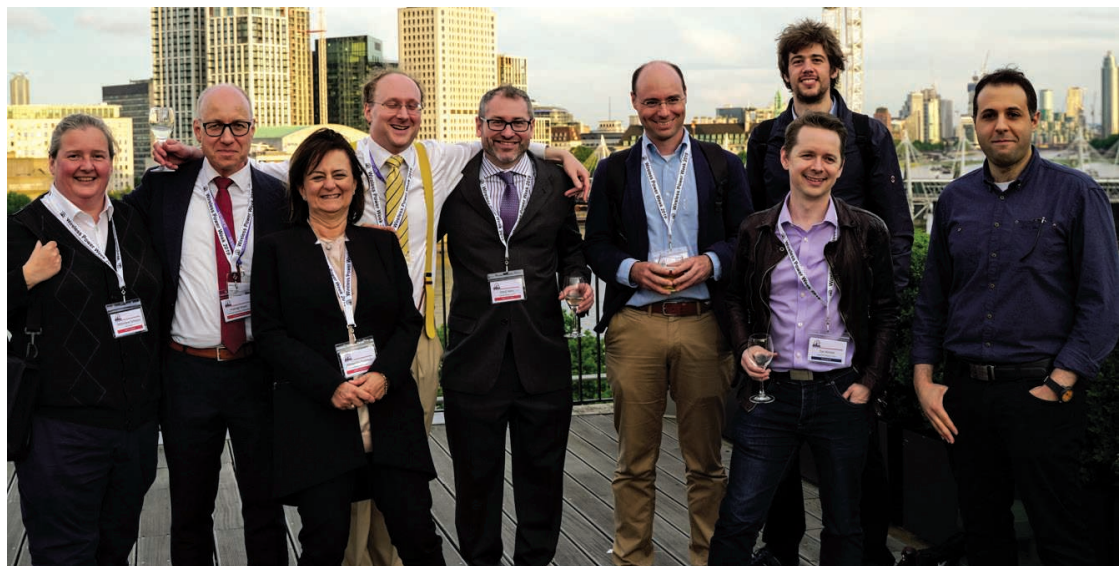

Figure 2. Attendees of the WPW2019 opening reception on the roof terrace of the IET'S Savoy Place.

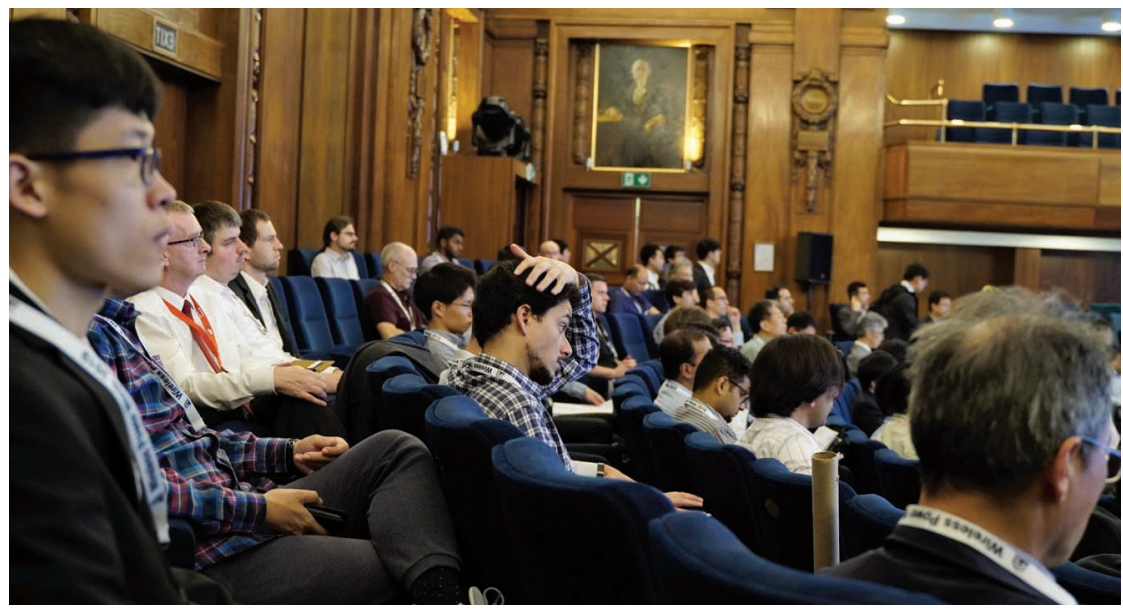

Figure 3. The audience in the Kelvin Lecture Theatre during the WPW2019 opening session.

Over the next four days, eight parallel WPTC and WoW sessions were held there and in the Turing Lecture Theatre, in addition to three plenary talks and two joint WPTC-WoW sessions. During the break-out sessions, 46 oral presentations were given in the WPTC and WoW tracks, 91 posters were presented for WPTC, and 41 posters were presented for WoW. The presentations were held in the Maxwell Library, where the industrial exhibition, with 14 exhibitors/sponsors, was also located (Figure 4). The colocation helped us to meet our goal of bridging the gap between academia and industry. Attendees were free to visit both the WPTC and WoW presentations, and they frequently moved between the Kelvin and Turing theaters during the sessions.

For the plenary sessions, we were excited to engage chief executive officers (CEOs) and chief technology officers (CTOs) from industry. Further bridging the gap between academia and industry were outstanding presentations on the future of wireless power transfer by Alex Gruzen (CEO of WiTricity, Watertown, Massachusetts), Alexander Gerfer (CEO/CTO of Würth Elektronik, Niedernhall, Germany), Mirko de Melis (lead scientist for Europe, the Middle East, and Africa at Medtronic, Dublin, Ireland), and Irina Khromova (head of science and technology for Metaboards, Oxford, United Kingdom).

Our invited speakers certainly spiced up the sessions. We thank Paul Wiener (vice president of strategic marketing, GaN Systems, Kanata, Canada), Dinesh Kithany (lead industry analyst, wireless power and power supplies, IHS Markit, London), Jürgen Meins (professor, University of Braunschweig, Germany), Hooman Kazemi (engineering fellow, Raytheon, Waltham, Massachusetts), Burak Ozpineci (group leader, power electronics and electric machinery, Oak Ridge National Laboratory, Tennessee), and Zoya Popovic (distinguished professor, University of Colorado, Boulder). 


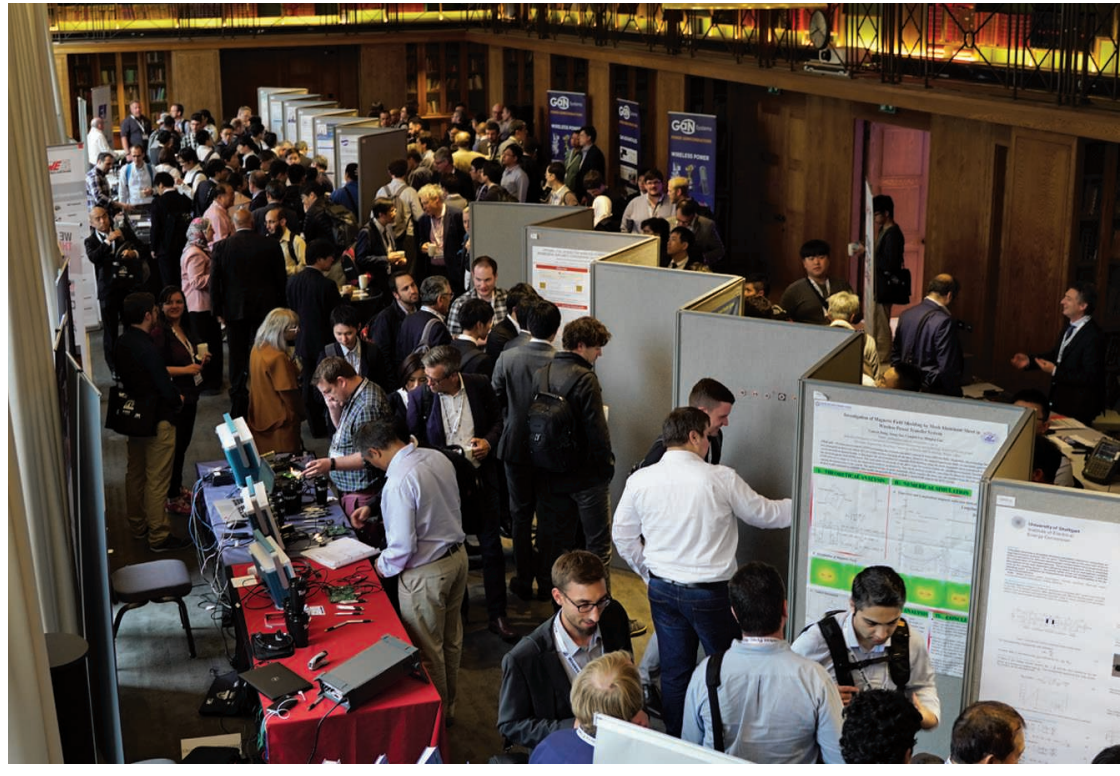

Figure 4. The industrial exhibition and poster session in the Maxwell Library of the IET'S Savoy Place.

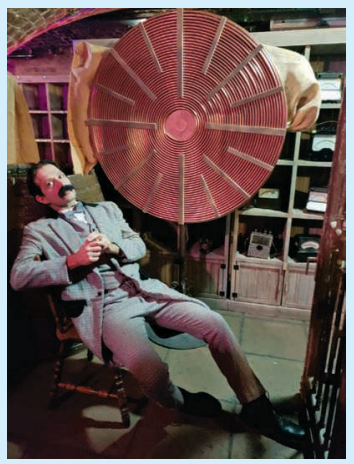

(a)

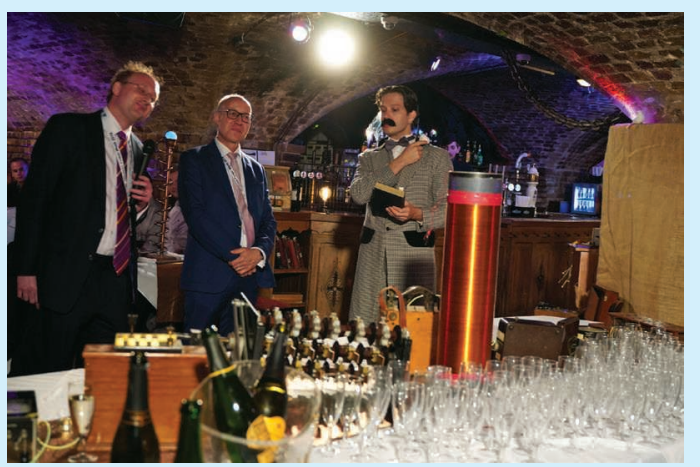

(b)
Figure 5. (a) Nikola Tesla (an actor) in a characteristic pose. (b) Tesla (right) poses with WPW2019 Chairs (from left) Paul Mitcheson and Hubregt Visser.
The panel session, on Wednesday, "The Future of WBG Devices in Power Processing and Wireless Power," gave rise to ample discussion and audience participation.

Before and throughout the conference, rumors circulated about the banquet that would be held in Tesla's secret, and only recently discovered, London laboratory. Expectations built up during the conference, and, by the time of the banquet, a queue had formed at the venue. People were not disappointed as the dinner not only was in the laboratory but "Nikola Tesla" was present [Figure 5(a)], announcing the meal at 8:10 p.m. sharp, his usual time for supper. Many people took the opportunity to have their photo taken with him [Figure 5(b)].

WPW2019 ended on 21 June at midday (Figure 6). After two joint WPTC-WoW sessions, awards were presented to the best and secondbest papers as well as the best WPTC and WoW talks, student papers, and posters. Following the awards presentations, the podium was turned over to the WPW2020 chairs to thank the attendees and close the meeting. WPW2020 will be held 5-9 May in Seoul, South Korea. The deadline for conference papers for technical review is 31 December 2019. We hope to see you in Seoul.

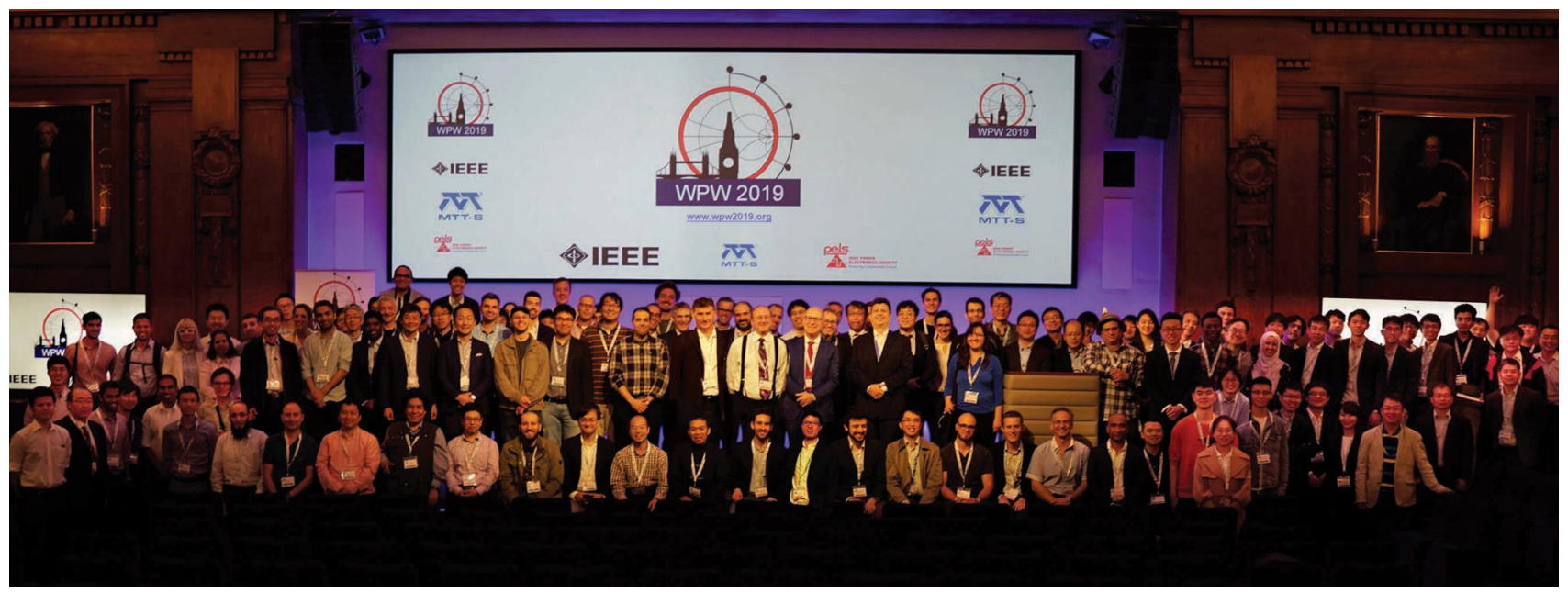

Figure 6. The "survivors" of WPW2019 at the conclusion of the conference. 